Quest Journals

Journal of Research in Business and Management

Volume 7 Issue 3 (2019) pp: 24-29

ISSN(Online $): 2347-3002$

www.questjournals.org

Research Paper

\title{
Impact of Customer Perceived Value on Loyalty: In Context Crm
}

\author{
Lutfi Ramadhan ${ }^{l}$, Dr. Yolanda MasnitaSiagian, $\mathbf{M M}^{2}$ \\ ${ }^{I}$ (Student, MercuBuana University, Jakarta, Indonesia) \\ ${ }^{2}$ (Lecturer, MercuBuana University, Jakarta, Indonesia) \\ Corresponding Author: Lutfi Ramadhan
}

\begin{abstract}
This study aims: 1) to Know whether the Customer Perceived Value affect Customer Relationship Management 2) to Know whether the Customer Relationship Management affect Loyalty and 3) to Know whether the Customer Perceived Value affect Loyaltymediated by CRM.This research is a quantitative approach, associative type. In this study, the population studied were 120 customers who were already members of Abbott Family Club loyalty as well who contacted via customer service on Pediasure Vanilla 850gr dairy products. And with samples that can describe population, then in determining the sample of this study using the technique non probability sampling with method Convenience Sampling.
\end{abstract}

KEYWORDS: Customer Perceived Value, CRM and Loyalty

Received 28 March, 2019; Accepted 08 April, 2019 () the Author(S) 2019.

Published With Open Access At www.Questjournals.Org

\section{INTRODUCTION}

The increasing consumption of dairy products and other livestock products brings important nutritional benefits to a large segment of the population of developing countries, although millions of people in developing countries still cannot afford better quality food because of higher costs. (Muehlhoff et al. 2013). Nutritional needs during infancy require more nutrition because toddlers (1-5 years) are a golden period. (Entie et al, 2017). Pusat Data danSistemInformasiPertanianSekretariatJenderal - Kementerian Pertanian (2017) In Indonesia, raw material for milk powder is more than imported liquid milk. BadanStatistik Indonesia (2017) average consumtion milk powder based on area in Indonesia in 2017 increase based on population in indonesia in consumtion milk. This condition makes milk producer always have to reach as many customers as possible to expand market share and get consumers who are loyal to their products.

Abbott Indonesia is the main producer that distributes and increases sales of formula milk including Pediasure, Gain Plus Advance, Gain School Advance, Isomil Plus Advance, and Ensure through customer service and through the marketplace in Indonesia. Another main focus to increase selling milk formula is giving knowledge for every consumers who buy milk formula as member loyalty Abbott Family Club. Abbott Family Club is club for customer who been faithfully using milk formula produced by Abott. Standardization implementation system Customer Relationship Management on Abbott is giving service on email, website, customer service and datawarehouse made to adjusting by customerneeds for the purpose have a detail information from customers. Implementation Customer Relationship Management including from member registration loyalty. Abbott have primary product on top selling with name Pediasure. In Indonesia, Pediasure Vanilla 850gr mostly liked at market. Many competitor have expanding market to Indonesia for selling formula milk and then Abbott must have a strategy to grow up sales of Pediasure.

Abbott have a strategy to expanding sales a product of Pediasure at customer service and ecommerce. With data collected by Abbott showing sales on customer service was highest sales within customer service and ecommerce. Top sales with not as member loyalty Abbott Family Club dominating through customer service. Customer service must have a strategy to reach top sales with member loyalty Abbott Family Club.

As sales progress, customer service receive information based on complaint delivered by customer when customer calling customer service. With complaint information from customers makes customer perceived value with customer relationship management must to evaluate full because if this problem not resolved, customer not to be loyalty and makes customer move to competitors. With complaint collected with customer service, customer service must to know about customer perceived value when customer call to ask about anything product of Pediasure. Because customer already giving time and costs to contact customer service. 
Based on the above background, the aim of this paper is to investigate impact customer perceived value on their intention to remain loyal as member loyalty Abbott Family Club, as mediated by customer relationship management.

\section{LITERATURE REVIEW}

\subsection{Customer Perceived Value and Loyalty}

Kotler (2016) Customer Perceived Value is also called the value perceived by the customer is the difference between prospective customers for all benefits and costs of perceived and alternative offers. According to The perceived value of customers is usually regarded as an exchange between two parties, one party gets a profit from the purchase and the other party receives benefits by consuming the product or service(Javeed et.al, 2017). Naami et al. (2017) The perceived value is defined as an evaluation of the customer from the costs paid to obtain certain goods and services and benefits found from certain goods or services. Jamrozy et al. (2016) Companies involved in creating value when they design and promote their products to prospective customers. The customer will evaluate the perceived value of the company's offerings and competitors in making the decision to consume. Lin et al. (2013) The perceived value has a strong impact beyond the satisfaction of new customers who switch from competitors because customers have accumulated shopping experience and value awareness. Customer perception will form a loyalty in the presence of other important factors that are considered important by customers, namely things that feel positive and a comfortable experience (Keshavarz et al. 2017)

Hypothesis 1: Customer Perceived Value are positively associated Customer Loyalty.

\subsection{CRM and Loyalty}

Darvish et al. (2012) in their study defined CRM as a customer-centered managerial strategy that aspires to build long-term relationships with its customers to benefit by using the knowledge of all customers.

The benefit of CRM is that it enables organizations not only to retain customers, but also allows more effective marketing, creates opportunities for cross-selling and opens possibilities in introducing new brands and products quickly (Naveen et al., 2014). Solimun et al. (2017) Loyalty has an important role in the company because maintaining customers will have an impact on the survival of the company by attracting and retaining customers. Various efforts can be made to achieve also retain customers through strategic stages and policies. Starting from the attention in meeting customer needs such as improving the process and quality of ongoing services to attract new customers and not only sell or provide good quality services as a process of achieving loyalty strategies (Santos et al. 2016).

Hypothesis 2: CRM are positively associated Customer Loyalty.

\subsection{CRM mediates the relationship of Customer Perceived Value and Customer Loyalty.}

El-Manstrly (2016) found that relationships within groups of customers will be stronger between what is perceived and customer loyalty by demonstrating competence and better understanding of customers and companies must remain focused on offering competitive and efficient prices with good quality services. Customer perceptions will form loyalty with important factors that are considered important by the customer are positive factors and comfortable experience (Keshavarz et al. 2017). According to Lin et al. (2013) Because the value received and satisfaction are different things as substantial formation

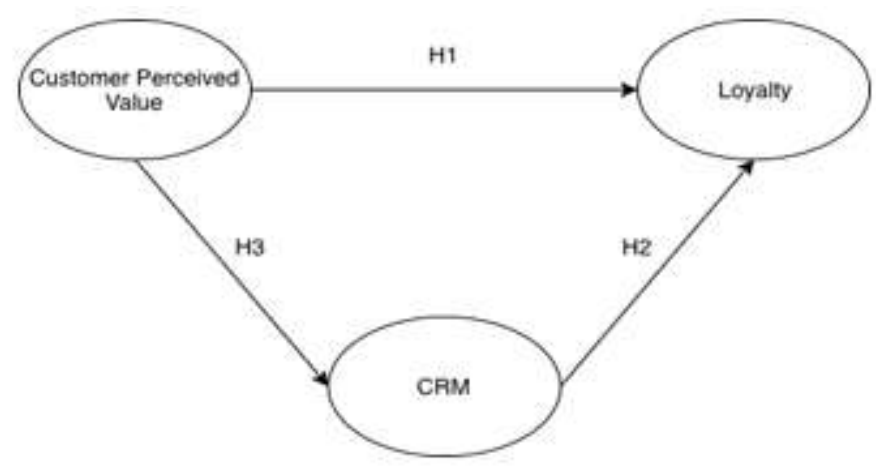

Figure 1. Research model

of loyalty. Ali et al. (2018) The company builds customer relationship management from customer experience with the aim of building, maintaining and satisfying its customers. According to Shaon et al. (2015) Customer relationship management $(\mathrm{CRM})$ is an effort to ensure that customer perceived value is more 
organized and makes them feel satisfied and loyal. In research using a CRM system, Palacios-Marques et al. (2016) explain loyal customer behavior will show positive behavior and behavior towards service and will build confidence in customers.

Hypothesis 3: Customer Perceived Value are positively associated Customer Loyalty with mediated relationship of Customer Relationship Management

\section{RESEARCH METHODOLOGY}

In preparing our research methods, one of the first question that we addressed was how best to capture the necessary survey data. The sampling technique in this study uses a type of non-probability sampling, namely the Convenience Sampling method. This is based on the criteria determined by the researcher (Ferdinand, 2014). In this study 120 samples were taken to 120 respondents and determined the criteria that the sample should be a customer who purchases Pediasure Vanilla 850gr milk products through customer service. Data obtained from the first source of either individuals or individuals, such as the results of interviews conducted by asking the customer's willingness when contacting customer service to be a respondent, if the customer agrees to be a respondent, the researcher will provide questionnaire questions to customers by contacting customers after making a purchase Milk Pediasure Vanilla 850gr. The survey questionnaire design is derived from multiple-item measurement scales. The measuring scale of items was Likert Scale analyses in a Five Point Scale where number 1 stands for strongly disagree (Completely Disagree) and number 5 stands for strongly agree (Completely Agree) and number 3 stands for no opinion or not important (Natural Opinion).

\section{RESULTS}

This study used structural equation modeling (SEM) with Lisrel 8.80 to test the relationship among the three elements in the proposed model. The measurement model was made up of five correlated theoretical constructs, including Customer Perceived Value (four items), CRM (eight items) and Loyalty (four items). We tested these variables to determine how this structural model fit the data. First, to test a measurement model, we conducted a confirmatory factor analysis (CFA) of a five-factor model applying a maximum likelihood (ML) method. This analysis was conducted by testing the reliability of each measurement model that identifies the capabilities of each indicator in explaining the latent variable. Construct is deemed reliable when the value of Construct Reliability (CR) is smaller than 0.7 or Construct Validity (CV) is smaller than 0.5.

Table 1 :Descriptive information for items

\begin{tabular}{|c|c|c|c|c|c|c|}
\hline Dimension & Items & $\begin{array}{c}\text { Factor } \\
\text { Loading }\end{array}$ & $t$-value & $\mathrm{CR}$ & $\mathrm{CV}$ & Reference \\
\hline & \multicolumn{3}{|l|}{ F1: Customer Perceived Value } & & & \\
\hline \multirow[b]{2}{*}{$\begin{array}{l}\text { Benefits } \\
\text { Obtained }\end{array}$} & $\begin{array}{l}\text { Products needed by customers } \\
\text { are easier to obtain through } \\
\text { customer service }\end{array}$ & 0.75 & 9.81 & \multirow{4}{*}{0,77} & \multirow{4}{*}{0.74} & \multirow{4}{*}{ Kotler (2016) } \\
\hline & $\begin{array}{l}\text { There are benefits obtained when } \\
\text { shopping using the loyalty } \\
\text { members through customer } \\
\text { service }\end{array}$ & 0.76 & 9.94 & & & \\
\hline \multirow{2}{*}{ Sacrifice Given } & $\begin{array}{l}\text { Customers will sacrifice to get a } \\
\text { product if they have to pay for a } \\
\text { more expensive product than } \\
\text { other products }\end{array}$ & 0.94 & 10.87 & & & \\
\hline & $\begin{array}{l}\text { Customers will sacrifice their } \\
\text { ability to get products faster than } \\
\text { getting products from direct } \\
\text { purchases }\end{array}$ & 0.93 & 9.51 & & & \\
\hline & \multicolumn{3}{|l|}{$F 2: C R M$} & & & \\
\hline \multirow{2}{*}{$\begin{array}{l}\text { Customer } \\
\text { Orientation }\end{array}$} & $\begin{array}{l}\text { Customer service is always } \\
\text { focused on understanding what } \\
\text { customers need }\end{array}$ & 0.81 & 6.59 & \multirow{4}{*}{0.94} & \multirow{4}{*}{0.84} & \multirow{4}{*}{$\begin{array}{c}\text { Chetioi et al. } \\
\text { (2017) }\end{array}$} \\
\hline & $\begin{array}{l}\text { Customer service is always } \\
\text { focused on handling problems } \\
\text { and providing solutions to } \\
\text { customers }\end{array}$ & 0.76 & 7.10 & & & \\
\hline \multirow[t]{2}{*}{$\begin{array}{l}\text { Managing } \\
\text { Knowledge }\end{array}$} & $\begin{array}{l}\text { Customer knowledge delivered } \\
\text { to customer service can be an } \\
\text { evaluation material for customer } \\
\text { service }\end{array}$ & 0.73 & 6.98 & & & \\
\hline & Customer service is able to adapt & 0.85 & 6.40 & & & \\
\hline
\end{tabular}




\begin{tabular}{|c|c|c|c|c|c|c|}
\hline & to current customer needs & & & & & \\
\hline \multirow{2}{*}{$\begin{array}{l}\text { Organizing } \\
\text { around CRM }\end{array}$} & $\begin{array}{l}\text { Speed and accuracy in } \\
\text { responding to customer needs are } \\
\text { in accordance with customer } \\
\text { needs }\end{array}$ & 0.78 & 6.79 & & & \\
\hline & $\begin{array}{l}\text { Customer service capability in } \\
\text { solving problems when } \\
\text { purchasing products }\end{array}$ & 0.64 & 7.26 & & & \\
\hline \multirow{2}{*}{$\begin{array}{l}\text { Incorporating } \\
\text { CRM-based } \\
\text { technology }\end{array}$} & $\begin{array}{l}\text { Purchasing system through } \\
\text { customer service that is easy to } \\
\text { use for customers and can be } \\
\text { integrated with customer needs }\end{array}$ & 0.79 & 6.81 & & & \\
\hline & $\begin{array}{l}\text { The implemented information } \\
\text { system does not make customers } \\
\text { wait for the get the product }\end{array}$ & 0.86 & 6.08 & & & \\
\hline & \multicolumn{3}{|l|}{ F3: Loyalty } & & & \\
\hline \multirow[b]{2}{*}{$\begin{array}{l}\text { Affective } \\
\text { Loyalty }\end{array}$} & $\begin{array}{l}\text { Customers will purchase } \\
\text { products using loyalty member }\end{array}$ & 0.67 & 5.00 & \multirow{4}{*}{0.81} & \multirow{4}{*}{0.77} & \multirow{4}{*}{$\begin{array}{l}\text { Irshad et al. } \\
\quad(2015)\end{array}$} \\
\hline & $\begin{array}{l}\text { Customers will repurchase } \\
\text { Pediasure vanilla } 850 \text { gr products } \\
\text { through customer service }\end{array}$ & 0.63 & 6.14 & & & \\
\hline \multirow[b]{2}{*}{$\begin{array}{c}\text { Behavioural } \\
\text { Loyalty }\end{array}$} & $\begin{array}{l}\text { Customers will recommend to } \\
\text { others to buy Pediasure vanilla } \\
850 \text { gr products through customer } \\
\text { service }\end{array}$ & 0.49 & 6.66 & & & \\
\hline & $\begin{array}{l}\text { More affordable prices on } \\
\text { Pediasure vanilla } 850 \mathrm{gr} \text { products } \\
\text { using member loyalty Abbot } \\
\text { Family Club will make } \\
\text { customers continue to buy } \\
\text { through customer service }\end{array}$ & 0.67 & 5.71 & & & \\
\hline
\end{tabular}

We estimated the structural analysis using the ML method, the results of which are shown in Table II. Overall, in the proposed model, the goodness-of-fit statistics revealed that the model reasonably fit the data $\left(\chi^{2}=\right.$ 192.91, $\mathrm{df}=101, \mathrm{p}<0.001, \chi^{2} / \mathrm{df}=1.91, \mathrm{CFI}=0.96, \mathrm{TLI}=0.96, \mathrm{RMSEA}=0.087 ;$ Figure 2).

First, in terms of the H1, the association between Customer Perceived Value and Loyalty was supported by the path coefficient of $0.40(t=4.02, \mathrm{p}<0.001)$, indicating that Customer Perceived Value had a significant impact on Loyalty. Second, for the $\mathrm{H} 2$, the association between the CRM and Loyalty was also supported by the estimate of $0.28(\mathrm{t}=2.69, \mathrm{p}<0.001)$. This result showed that CRM was a significant antecedent of Loyalty. Finally, H3 was supported by a path coefficient of $0.11(t=9.68, p<0.001)$, indicating that Customer Perceived Value mediated by CRM was a significant predictor of Loyalty.

Table 2 :Structural parameter estimates

\begin{tabular}{|c|c|c|c|}
\hline No & Hypothesis path & Standardized path coefficients (T-Value) & Result \\
\hline H1 & Perceived Value $\rightarrow$ Loyalty & $0.40(4.02)$ & Supported \\
\hline H2 & CRM $\rightarrow$ Loyalty & $0.28(2.69)$ & Supported \\
\hline H3 & $\begin{array}{c}\text { Perceived Value } \rightarrow \text { (mediated by } \\
\text { CRM) Loyalty }\end{array}$ & $0.11(9.68)$ & Supported \\
\hline \multicolumn{2}{|c|}{ Notes: $\chi^{2}=192.91, \mathrm{df}=101, \mathrm{p}<0.001, \chi^{2} / \mathrm{df}=1.91, \mathrm{CFI}=0.96, \mathrm{TLI}=0.96$, RMSEA $=0.087 ; * * * \mathrm{p}<0.001$} \\
\hline
\end{tabular}

Figure 2.

The result of the structural model

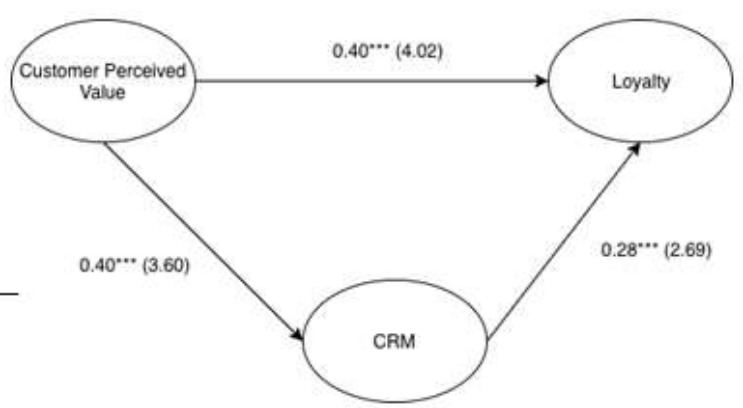




\section{CONCLUSION}

In this study, we examined the association among Customer Perceived Value, CRM, and Loyalty in the context of member loyalty Abbott Family Club. We also analyzed the moderating role of the level of involvement of member loyalty Abbott Family Club between Customer Perceived Value and CRM and Loyalty. Overall, this research showed that Customer Perceived Value significantly influenced Loyalty. On the other hand, Customer Perceived Value have significant impact on Loyalty, while Customer Perceived Value influenced CRM. These results indicated that member loyalty Abbott Family Club doing by customers to obtain Pediasure Vanilla 850gr through customer service get a positive customer experience regarding information about a product. Another thing that needs to be improved is the benefit dimension obtained with the dimensions of behavioral loyalty. This means that if you want to increase the purchase of Pediasure Vanilla 850gr, you have to increase the benefits obtained if you make purchases through customer service so that customers get experience that will always be remembered after purchasing product. Keshavarz et al. (2018) there is a significant influence between customer perceived value and loyalty. El-Manstrly (2016) also found that the perceived value of customers had a positive and significant effect. Hänninen (2017) also found a significant influence between the value perceived by customers and loyalty.

In addition, Customer Perceived Value had an indirect impact on Loyalty through CRM. The result also indicated that the level of involvement moderated the association between Customer Perceived Value and CRM. Hence, it can be concluded that understanding of customers is an important factor in shaping positive experiences in every sale of Pediasure Vanilla 850gr through customer service. Another thing that needs to be improved is the dimension of combining CRM-based technology with behavioral loyalty dimensions. That is, the company is required to always innovate in terms of technology, especially in terms of the sales process of Pediasure Vanilla 850gr in order to enhance a positive experience for customers. Bahri-Ammari et al. (2016) there is a significant influence between CRM and loyalty. The next study conducted by Khedkar (2015) also found CRM to have a positive and significant effect on loyalty.

This study indicates that if the Customer Perceived Value and happy, and assuming that the Pediasure Vanilla $850 \mathrm{gr}$ and services received by the customer is measurable and offer competitive value, the customer will then remain loyal to purchase Pediasure Vanilla 850gr through customer service for the long term. In conclusion it is important for Abbott to focus on the development of customer loyalty programs because strong loyalty will lead to profitability and competitive advantage in CRM system. This will enable them to sustain their business in the present competitive environment.

\section{REFERENCES}

[1]. Agustina, Titin. 2017. Outlook SusuKomoditasPertanian Sub SektorPeternakan. Jakarta:Pusat Data Dan SistemInformasiPertanianSekretariatJenderal Kementerian Pertanian

[2]. Ali, Sufyan; Ali, Mohammed. (2018). Impact Of Consumer Relationship Management On Consumer Satisfaction, Loyalty Programs And Customer Retention In Bankikng Sector Of Pakistan. Arabian Journal Of Business And Management Review (Oman Chapter), 7(3), 66-72.

[3]. BadanStatistikNasional. 2017. PengeluaranUntukKonsumsiPenduduk Indonesia Per Provinsi, Maret 2017. DiunduhPada Https://Www.Bps.Go.Id/Publication/2017/12/28/B7f6c6416d1f53e29ad61edd/Pengeluaran-Untuk-Konsumsi-Penduduk-IndonesiaPer-Provinsi--Maret-2017.Html, PadaTanggal 2 Januari 2018.

[4]. Bahri-Ammari, Nedra; S. Soliman, Khalid. (2016). The Effect Of CRM Implementation On Pharmaceutical Industry's Profitability The Case Of Tunisia. Management Research Review, 39(8), 854-878.

[5]. Darvish, Hasan. Et Al. (2012). Studying The Customer Relationship Management: A Case Study At Persian Technology Firm. Economic Insights - Trends And Challenges, 64(2), 1-18.

[6]. El-Manstrly, Dahlia. (2016). Enhancing Customer Loyalty: Critical Switching Cost Factors. Journal Of Service Management, 27(2), 144-169.

[7]. Ferdinand, Augusty. 2014. MetodePeneltianManajemenPedomanPenelitianUntukPenulisanSkripsiTesis Dan DisertasillmuManajemen. Semarang:BadanPenerbitUniversitasDiponegoro

[8]. Hänninen Nora; Karjaluoto, Heikki (2017). The Effect Of Marketing Communication On Business Relationship Loyalty. Marketing Intelligence \& Planning, 35(4), 458-472

[9]. Jamrozy, Ute; Lawonk, Kesinee. (2016). The Multiple Dimensions Of Consumption Values In Ecotourism. International Journal Of Culture, Tourism And Hospitality Research, 11(1), 18-34.

[10]. Javed, Farheen; Cheema, Sadia. (2017). Customer Satisfaction And Customer Perceived Value And Its Impact On Customer Loyalty: The Mediational Role Of Customer Relationship Management. Journal Of Internet Banking And Commerce, 22, S8

[11]. Keshavarz, Yousef; Jamshidi, Dariyoush. (2018). Service Quality Evaluation And The Mediating Role Of Perceived Value And Customer Satisfaction In Customer Loyalty. International Journal Of Tourism Cities, 4(2), 220-244.

[12]. Khedkar (2015). Effect Of Customer Relationship Management On Customer Satisfaction And Loyalty. International Journal Of Management (IJM), 6(5), 1-7.

[13]. Kotler, Philip And Kevin Lane Keller. 2016. Marketing Management 15e. New Jersey: Pearson Prentice Hall, Inc.

[14]. Lin, Chien-Hsin; Kuo, Beryl Zi-Lin. (2013). Escalation Of Loyalty And The Decreasing Impact Of Perceived Value And Satisfaction Over Time. Journal Of Electronic Commerce Research, 14(4), 348-362.

[15]. Muehlhoff, Ellen; Bennett, Anthony, Untung; Mcmahon, Deirdre. (2013). Milk And Dairy Products In Human Nutrition. Food And Agriculture Organization Of The United Nations, 5-51.

[16]. Naami, Abdollah. Et Al. (2017). The Effect Of Perceived Value, Perceived Risk, And Price On Customers Buying Intention (Case Study: Employees Of Presov Electronics Company). International Review Of Management And Marketing, 7(5), 164-170. 
[17]. Naveen, Sudhamsetti; M.Venkataramana. (2014). Customer Relationship Management: Overview \&Emerging Principles. International Journal Of Scientific And Research Publications, 4(5).

[18]. Palacios-Marques, Daniel. Et Al. (2016). The Use Of Customer-Centric Philosophy In Hotels To Improve Customer Loyalty. Journal Of Business \& Industrial Marketing, 31(3), 339-348.

[19]. Rosela, Entie; Hastuti, TulusPuji; Triredjeki, Hermani. (2017). Hubungan Status GiziDenganPerkembanganAnakUsia 1 Sampai 5 Tahun Di KelurahanTidar Utara, Kota Magelang. JurnalKeperawatanSoedirman (The Soedirman Journal Of Nursing), $12(1), 28$.

[20]. Santos, Carlos; Isaias, Pedro. (2016). After-Sales AndCrm: Their Role As A Differentiation Strategy For Clients. Iadis International Journal On Computer Science \& Information Systems, 11(2), 66-72.

[21]. Shaon, Kamrul Islam; Rahman, H., S. M.. (2015). A Theoretical Review Of CRM Effects On Customer Satisfaction And Loyalty. Central European Business Review, 4(1), 23-36.

[22]. Solimun; Fernandes, AdjiAchmad Rinaldo. (2018). The Mediation Effect Of Customer Satisfaction In The Relationship Between Service Quality, Service Orientation, And Marketing Mix Strategy To Customer Loyalty. Journal Of Management Development, 37(1), 76-87.

Lutfi Ramadhan" Impact of Customer Perceived Value on Loyalty: In Context Crm" Quest Journals Journal of Research in Business and Management, vol. 07, no. 03, 2019, pp 24-29 